\title{
Perception of Social Studies Teachers on Home Factors Contributing to Violent Behavior among Teenagers in Osun State, Nigeria
}

\author{
Dr. B. A. Adeyemi ${ }^{1}$ \& Dr. P. A. Amosun ${ }^{2}$ \\ ${ }^{1}$ Institute of Education, Faculty of Education Obafemi Awolowo University, Ile-Ife, Nigeria. +2348033819274 \\ ${ }^{2}$ Department of Teacher Education, Faculty of education, University of Ibadan, Ibadan, Nigeria. +2348038606505 \\ Correspondence: Dr. B. A. Adeyemi, Institute of Education, Faculty of Education Obafemi Awolowo University Ile-Ife, \\ Osun State, Nigeria
}

Received: March 2, 2016

doi:10.11114/ijsss.v4i5.1491 (1114/1jsss.v4i5.1491

Accepted: March 22, 2016

Available online: March 24, 2016

URL: http://dx.doi.org/10.11114/ijsss.v4i5.1491

\begin{abstract}
The study examined the perception of Social Studies teachers on home factors contributing to violent behaviour among teenagers. It also identified the causes of violent behaviour among teenagers and highlighted the methods of resolving violent behaviour among teenagers. This was with a view of curbing violent behaviour among teenagers. The study adopted survey design. The population for this study consisted of teachers in Junior Secondary Schools in the state. A total of 115 teachers were purposively selected in Osun State Junior Secondary Schools. All the selected teachers were Social Studies teachers. The questionnaire titled "Teachers' Perception of Home Factors Contributing to Violent Behaviour among Teenagers" (TPHFCVB) was developed by the investigators to elicit information from the respondents and their responses were subsequently analysed with the use of Frequency Distribution Tables, Percentages and Factor Analysis. Results showed that 6 principal components explained nearly $73 \%$ of the variability in the original 21 variables. Also the results revealed that there were six home factors contributing to violent behaviour among teenagers which were: single parenting, over confidence, poor home, over protection and dependency on family, poor relationship between parents and children and coming from wealthy home. However, it was shown that 3 principal components explained nearly $70 \%$ of the variability in the original 11 variables. The first component highly correlated with being victims of physical abuse, exposure to violent films and increased stress and conflicts. The results further revealed that 7 variables had very high values that were very close to 1 . This proved that all these variables were good methods of resolving violent behaviour among teenagers. The study concluded and inferred that there were several home and generic factors contributing to violent behaviour among teenagers in Osun State. However, organizing sex education and parenting programmes by the school couple with monitoring the type of films children watch can go a long way in suppressing violent tendency among teenagers.
\end{abstract}

Keywords: teachers' perception, home variables, violent behaviour, teenagers

\section{Introduction}

Violent behaviour is an issue of global concern. Historically, in many cultures, violent behaviour has been an accepted fact of life. In recent years, it has begun to be viewed as a criminal problem. However, in many societies such as the Nigerian society, it is still culturally acceptable. Violent behaviour is the persistent abuse of anyone in the home in a way that causes pain, distress or injury. It refers to any abusive treatment of one family member by another, violating the law of basic human right.

Violent behaviour occurs globally (Dahlberg and Krug, 2002, UNICEF, 2005). Families from all social, racial, economic, educational and religious background experience home violence in different ways. Lehmann (1995); Kitzmann, Gaylord, Holt, \& Kenny (2003); Dodd (2009); Lazenbatt \& Thompso-Cree (2009); report that in Nigeria each year, teenage girls experience physical assaults and rape while teenage boys experience physical assaults. In some parts of the third world generally and in West Africa, in particular, home violence is prevalent and reportedly justified and condoned in some cultures.

Traditionally, in Nigeria, as in many other African countries, the beating of wives and children is widely sanctioned as a form of discipline (UNICEF, 2001). Therefore parents believe that in beating their children they are instilling discipline in them, much the same way as in husbands beating their wives, who are regarded as children prone to discipline. 
Violence among teenagers is not a new problem. It occurs between two or more individuals as interpersonal violence, or it involves identifiable groups in the society and erupts as intergroup violence between two or more different religions or ethnic groups. For centuries, violence has been a commonplace feature of school life with its causes embedded in the social, cultural, historical and economic contexts of its time (Leach, 2003). The focus of violence can be individuals, objects or the school itself, and the nature of the damage can be psychological, physical or material. Since the middle of the 20th century, violence among teenagers has increasingly been viewed as a violation of their fundamental human rights, in particular of their right to physical safety and psychological security and well-being (Rukundo, 2009). In addition, there has been recognition that either schools can help to prevent violence against teenagers or that they create an environment that reinforces violent attitudes. Generally, many teenagers operate in their homes irrespective of their cultures or countries of origin. Homes provide an environment that shapes their behaviour in one way or another. A 1994 National survey in suburban, urban and rural schools in Nigeria found that two major factors were held responsible for violence among teenagers: disintegration of the family; and increased depiction of violence in the media and popular music. Other factors included; alcohol and drug abuse, and easy access to weapons, such as guns. Poverty and inequitable educational opportunities also predispose teenagers' violence (Ohsako, 2007). Violence occurs in all types of settings such as schools and college campuses. Clearly, the nature of violence changes with the norms of the school and what is expected of pupils. Violence undermines the notion that school days are the happiest in a learner's life. Examples of violent behavior in schools include rioting, sexual harassment, fighting and bullying. These activities have detrimental consequences on the running of the schools' activities and on the teenagers' personal security and emotional stability. Violence may contribute to physical deformities, humiliation, disinterestedness, withdrawal, poor academic performance, high drop - out rates and even death of affected students (Volpe 1996; Obi \& Ozumba, 2007; Ruto, 2009; Miller, 2010)

Violent behaviour is one of the practices that have scared teachers, parents and students. Some students have had to die or suffer permanent deformities. Kangare (2008) asserted that violence has been going on since 1970 especially among teenagers. In secondary schools, sexual violence has been identified as one of the most teething social problem female teenagers are facing. Sexual violence has made children, girls, no longer safe in their own homes, schools, work places or on roads.

Teenagers attending schools located in violent or poor neighborhoods where discrimination against ethnic or other groups is accepted are also more likely to experience violence. Most victims do not report what they are suffering because they blame themselves and feel ashamed.

Moreover, few victims believe their schools will take real action to improve the situation. Intimidated teenagers tend to have a reduced network of friends who might give support and protection. Studies conducted in Western Province specifically by Mutsotso (2004) \& Simatwa (2007) identified various factors contributing to violence in schools in general. However, the current study tried to fill the gap by establishing teachers' Perception of factors contributing to violent behavior among teenagers in Nigeria. Establishing home factors as they are perceived, would equip policy makers and planners, parents, teachers and school administrators with knowledge and skills that would help minimize violent behavior among secondary school students specifically in Nigeria.

\subsection{Statement of the Problem}

The incessant violent behaviour among teenagers has been a major concern of teachers, parents, and educationists. In spite of emphasis on home factors contributing to violent behaviour among teenagers, it seems that home violent behaviour among teenagers has not been adequately addressed. Several researchers have revealed that home factors contribute to violent behaviour among teenagers in Nigeria. Nonetheless, nothing tangible has been done on the issues to curb the problem. Hence, the study therefore addresses such problems as:

i. What are the causes of violent behaviour among teenagers?

ii. Can violent behaviour be traced to the society or home?

iii. What are the factors contributing to violent behaviour among teenagers?

iv. What are the types of home violence among teenagers?

v. What are the negative effects of violence among teenagers?

vi. What are the appropriate measures necessary to address home violence among teenagers? 


\section{Purpose of the Study}

The purpose of this survey work is based on teacher's perception of home factors contributing to violent behaviour among teenagers in order to get more information about home violent among teenagers. The specific objectives are to:

vii. identify the causes of violent behaviour among teenagers;

viii. assess perception of teachers on how home factors contribute to violent behaviour among teenagers; and

ix. Highlight the methods of resolving violent behaviour among teenagers.

\section{Methodology}

This study adopted survey research design. The population of the study consisted of Junior Secondary School teachers in Osun State. The study sample consisted of 115 Social Studies teachers that were purposively selected from Junior Secondary Schools in Osun State. An instrument titled: 'Teachers Perception of Home Factors Contributing to Violent Behaviour among Teenagers in Osun State' was used. The questionnaire consisted of four sections. Section A of the questionnaire was based on demographical information such as sex, age, religion, ethnic group, marital status, educational level, and year of teaching experience. Section B measured the perception of teachers' on home factors contributing to violent behaviour among teenagers while section $\mathrm{C}$ focuses on various causes of violent behaviour among teenagers and the last section examines various methods that could be adopted to resolve violent behaviour among teenagers. The instrument was validated before use and yielded 0.87 with the use of Cronbach alpha. The information obtained from the instrument used for data collection was analysed with the use of descriptive statistics (i.e frequency distribution Table) and Factor Analysis for Data Reduction.

\section{Results}

\subsection{Socio-Demographic Profiles of the Respondents}

The distribution of respondents' socio-economic and demographic characteristics covered such measures as sex, age, religion, ethnic group, marital status, educational levels and years of teaching experience. The data provided insights on the basic profiles of respondents who were interviewed during the survey and they were presented in table 1 .

Table 1. Socio-demographic Characteristics of the Respondents

\begin{tabular}{|c|c|c|c|}
\hline VALID & CATEGORY & FREQUENCY & PERCENTAGE (\%) \\
\hline \multirow[t]{3}{*}{ SEX } & Male & 51 & 44.3 \\
\hline & Female & 64 & 55.7 \\
\hline & TOTAL & 115 & 100.0 \\
\hline \multirow[t]{4}{*}{ AGE } & $25-30$ years & 29 & 25.2 \\
\hline & $30-45$ years & 49 & 42.6 \\
\hline & 45 years and above & 37 & 32.2 \\
\hline & TOTAL & 115 & 100.0 \\
\hline \multirow[t]{4}{*}{ RELIGION } & Christianity & 90 & 78.3 \\
\hline & Islam & 23 & 20 \\
\hline & Traditional & 2 & 1.7 \\
\hline & TOTAL & 115 & 100.0 \\
\hline \multirow[t]{4}{*}{ ETHNIC GROUP } & Yoruba & 95 & 82.6 \\
\hline & Igbo & 19 & 16.5 \\
\hline & Hausa & 1 & 0.9 \\
\hline & TOTAL & 115 & 100.0 \\
\hline \multirow[t]{5}{*}{ MARITAL STATUS } & Single & 29 & 25.2 \\
\hline & Married & 83 & 72.2 \\
\hline & Separate & 2 & 1.74 \\
\hline & Divorce & 1 & 0.9 \\
\hline & TOTAL & 115 & 100.0 \\
\hline \multirow{4}{*}{$\begin{array}{l}\text { EDUCATIONAL } \\
\text { LEVEL }\end{array}$} & NCE & 73 & 63.5 \\
\hline & B.Sc./B.Ed & 30 & 26.1 \\
\hline & Post Graduate & 12 & 10.4 \\
\hline & TOTAL & 115 & 100.0 \\
\hline
\end{tabular}




\begin{tabular}{ccc}
$1-5$ years & 2 & 1.7 \\
$6-10$ years & 25 & 21.8 \\
$10-15$ years & 26 & 22.6 \\
15 years and above & 62 & 53.9 \\
\hline TOTAL & $\mathbf{1 1 5}$ & $\mathbf{1 0 0 . 0}$ \\
\hline
\end{tabular}

Source: Authors Field Survey.

On gender, the data indicated that 44.3 percent of the respondents were males and 55.7 percent were females. Thus, women dominated the teaching occupation that was covered in this survey. Analyses of the respondents' age distribution showed that 25.2 percent and 42.6 percent of the participants in the teaching job were in their prime age. Other participants that fall under 45 years and above were $37(32.2 \%)$. As regards the religion of the respondents, about 78.3 percent were Christians, 20 percent were Muslim, while 1.7 percent were Traditional Worshipers.

On the basis of educational level, the distribution showed that 63.5 percent (73) had National Certificate in Education (NCE), 26.1 percent (30) had B.Sc./B.Ed qualifications and 10.4 percent (12) had post graduate qualification. These statistics indicated that many of the participants that this survey covered underwent normal methods of teaching training. Understandably, the Yoruba people dominated the selected respondents and specifically they were 95 (82.6\%), Igbos were $19(16.5 \%)$ while the remaining $1(0.9 \%)$ was an Hausa man. Thus, major participants in teaching occupation in the State were the Yorubas and Igbos.

The marital status of the respondents indicated that $72.2 \%$ (83) of all the respondents were married men and women. Likewise, $25.2 \%$ (29) were single, $1.74 \%$ (2) were separate while the remaining 1 person $(0.9 \%)$ was divorce. Years of teaching experience of the teachers that this survey covered showed that over $95 \%$ of the respondents have more than 5 years teaching experience. It is shown from table 1 that participants with $1-5$ years teaching experience were $2(1.7 \%)$, 6 - 10 years teaching experience were $25(21.8 \%), 10-15$ years were $26(22.6 \%)$ and participants with 15 years and above teaching experience were $62(53.9 \%)$. This is an indication that this survey captured the large proportion of participants expected to have adequate experience of the survey's subject matter.

RESEARCH QUESTION 1: What is the perception of Social Studies teachers on home factors contributing to violent behaviour among teenagers?

This is presented in Table 2. It is also diagrammatically illustrated with Scree Plot.

Table 2. Home factors that influence violent behaviour among teenagers (teachers' perception)

\begin{tabular}{cccc}
\hline Component & Total & $\begin{array}{c}\text { Initial Eigenvalues } \\
\text { \% of Variance }\end{array}$ & Cumulative \% \\
\hline 1 & 4.804 & 22.875 & 22.875 \\
2 & 3.618 & 17.227 & 40.102 \\
3 & 2.505 & 11.928 & 52.030 \\
4 & 1.910 & 9.093 & 61.123 \\
5 & 1.536 & 7.312 & 68.435 \\
6 & 1.046 & 4.981 & 73.416 \\
7 & .883 & 4.207 & 77.623 \\
8 & .797 & 3.796 & 81.419 \\
9 & .713 & 3.395 & 84.814 \\
10 & .649 & 3.089 & 87.903 \\
11 & .458 & 2.182 & 90.085 \\
12 & .436 & 2.075 & 92.161 \\
13 & .418 & 1.989 & 94.149 \\
14 & .305 & 1.452 & 95.601 \\
15 & .255 & 1.212 & 96.813 \\
16 & .220 & 1.048 & 97.861 \\
17 & .170 & .808 & 98.669 \\
18 & .134 & .638 & 99.307 \\
\hline
\end{tabular}




\begin{tabular}{llcc}
\hline 19 & .083 & .396 & 99.703 \\
20 & .036 & .171 & 99.874 \\
21 & .027 & .126 & 100.000
\end{tabular}

Extraction Method: Principal Component Analysis.

Source: Authors Field Survey.

With the use of factor analysis, it is statistically required that Eigen value greater than one (1) under total column is extracted. So, the first six eigenvalues greater than one (1) under total column are the principal components that form the extracted solution. From the Table 2, it is shown that 6 principal components explain nearly $73 \%$ of the variability in the original 21 variables. In view of this, we can considerably reduce the complexity of the data set by using these 6 components, with only $5 \%$ loss of information.

\section{Scree Plot}

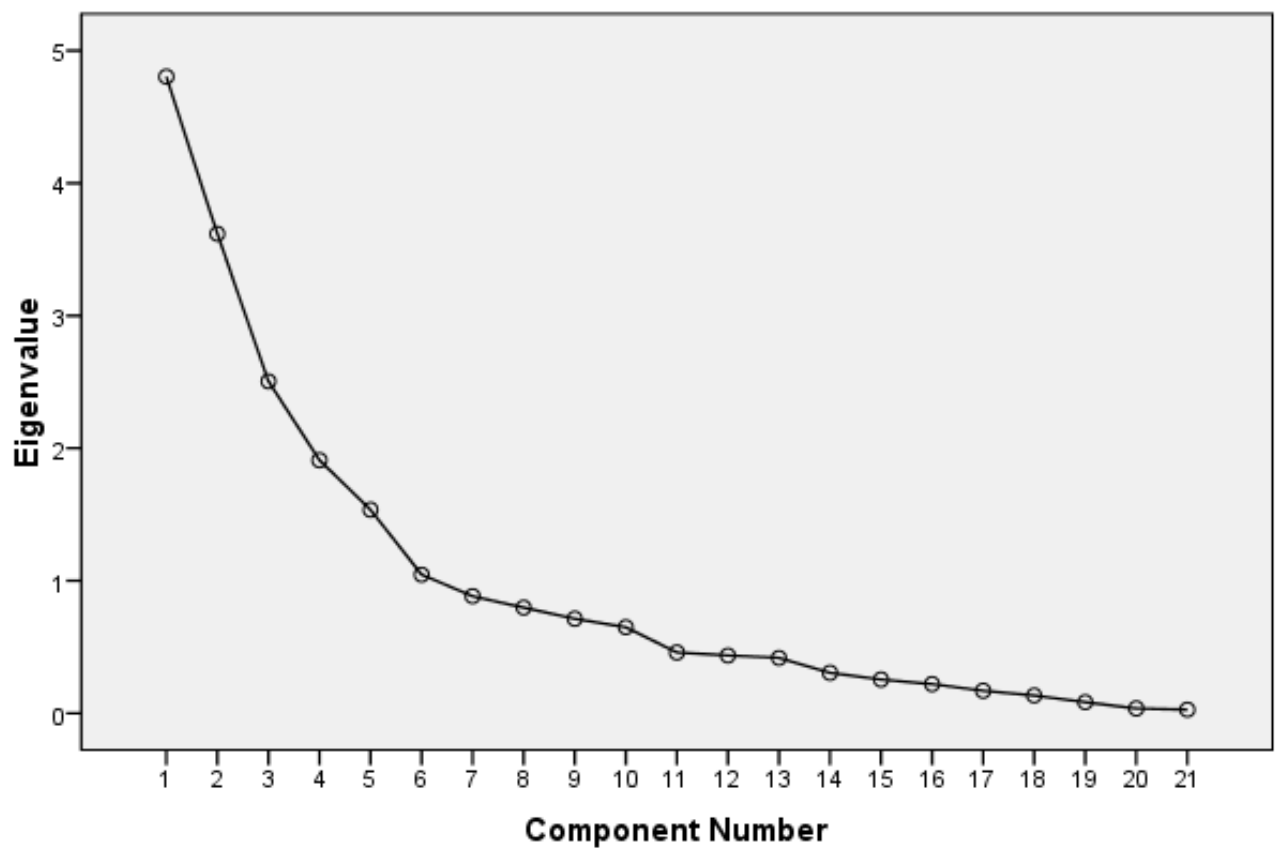

Figure 1.

Source: Authors Field Survey.

The Eigen value of each component in the initial solution is plotted on the scree plot, and it is indicated from the above figure that, 6 components are the optimal number of components on the steep slope. The components on the shallow slope contribute little to the solution. The last big drop occurs between the sixth and seventh components, so using the first 6 components is an easy choice. 
Table 3. Six principal component factors that influence violent behaviour among teenagers (teachers' perception)

\begin{tabular}{|c|c|c|c|c|c|c|}
\hline & \multicolumn{6}{|c|}{ Component } \\
\hline & 1 & 2 & 3 & 4 & 5 & 6 \\
\hline $\begin{array}{l}\text { Inability to meet parental } \\
\text { expectation }\end{array}$ & .027 & .136 & .729 & .329 & .125 & -.246 \\
\hline $\begin{array}{l}\text { Coming from poor home } \\
\text { background }\end{array}$ & -.044 & .042 & .844 & -.091 & .113 & .174 \\
\hline $\begin{array}{l}\text { Gossiping of the teachers by } \\
\text { student }\end{array}$ & .082 & .006 & .821 & .130 & .033 & .185 \\
\hline $\begin{array}{l}\text { Over protection } \\
\text { dependency on the family }\end{array}$ & -.019 & .050 & .105 & .915 & .008 & .031 \\
\hline $\begin{array}{l}\text { Parent general breakdown of } \\
\text { morals in the society }\end{array}$ & -.044 & -.068 & .232 & .773 & -.006 & -.164 \\
\hline Being orphans & .923 & -.101 & -.079 & -.055 & .026 & .030 \\
\hline Being a first born & .963 & -.091 & .041 & .006 & .010 & .042 \\
\hline Having single parent & .966 & -.096 & -.017 & -.060 & .055 & -.018 \\
\hline $\begin{array}{l}\text { Fear of being maltreated by } \\
\text { older siblings }\end{array}$ & .912 & -.007 & .147 & -.062 & -.067 & .104 \\
\hline $\begin{array}{l}\text { Poor relationship between } \\
\text { parents and children }\end{array}$ & .086 & -.032 & .079 & .047 & 673 & -.073 \\
\hline Parent being violent themselves & .064 & .031 & .439 & .020 & .597 & .112 \\
\hline $\begin{array}{l}\text { Exposure to violent films and } \\
\text { movies }\end{array}$ & -.121 & .097 & -.278 & .435 & .478 & -.009 \\
\hline $\begin{array}{l}\text { Come from wealthy home } \\
\text { background }\end{array}$ & .349 & .176 & .252 & -.064 & -.162 & .631 \\
\hline Come from broken homes & -.125 & .127 & .167 & -.129 & .544 & .576 \\
\hline Low level of home supervision & -.126 & .626 & .080 & .038 & .464 & -.200 \\
\hline $\begin{array}{l}\text { Manner of disciplining children } \\
\text { at home }\end{array}$ & -.273 & .743 & -.015 & -.066 & .347 & -.107 \\
\hline Experiencing mental illness & -.124 & .778 & .141 & -.175 & .038 & -.193 \\
\hline Ethnic violence & .079 & .764 & .013 & .162 & .049 & .218 \\
\hline Being over confident & -.007 & .844 & .020 & .053 & -.213 & .132 \\
\hline $\begin{array}{l}\text { Desired to be loved by both } \\
\text { parent and teachers }\end{array}$ & -.013 & .802 & .020 & .100 & -.106 & .368 \\
\hline $\begin{array}{l}\text { Experiencing anxiety problems } \\
\text { e.g. temper and depression }\end{array}$ & -.249 & .446 & -.211 & .508 & .291 & .246 \\
\hline
\end{tabular}

Source: Authors Field Survey.

It is indicated in Table 3 that, there were six home factors contributing to violent behaviour among teenagers. The first component was highly correlated with having single parent and it has 0.966 component value. The second component was highly correlated with being over confidence and it has 0.844 component value. The third component was highly correlated with coming from poor home and it has 0.844 component value. The fourth component was highly correlated with over protection and dependency on the family and it has 0.915 component value. The fifth component was highly correlated with poor relationship between parents and children and it has 0.673 component value. The sixth component was highly correlated with coming from wealthy home and it has 0.631 component value.

So, it can be empirically deduced from the principal component analysis that, having single parent, being over confidence, coming from poor home, over protection and dependency on the family, poor relationship between parents and children and coming from wealthy home were the home factors contributing to violent behaviour among the teenagers, from the perception of the teachers covered in the survey.

Research Question 2: What are the causes of violent behaviour among teenagers? 
This section presented the causes of violent behaviour among teenagers, form generic point of view. This is presented in Table 4 on the following pages. It is also graphically illustrated with scree plot.

Table 4(i). Generic factors influencing violent behaviour among teenagers

\begin{tabular}{cccc}
\hline Component & Total & $\begin{array}{c}\text { Initial Eigenvalues } \\
\text { \% of Variance }\end{array}$ & Cumulative \% \\
\hline 1 & 4.337 & 39.424 & 39.424 \\
2 & 2.241 & 20.370 & 59.794 \\
3 & 1.168 & 10.621 & 70.415 \\
4 & .974 & 8.853 & 79.269 \\
5 & .696 & 6.331 & 85.600 \\
6 & .558 & 5.072 & 90.672 \\
7 & .343 & 3.121 & 93.793 \\
8 & .254 & 2.312 & 96.105 \\
9 & .226 & 2.054 & 98.159 \\
10 & .141 & 1.281 & 99.439 \\
11 & .062 & .561 & 100.000
\end{tabular}

Extraction Method: Principal Component Analysis.

\section{Source: Authors Field Survey.}

With the use of factor analysis, it is statistically required that eigenvalue greater than one (1) under total column is extracted. So, the first three eigenvalues that are greater than one (1) under total column are the principal components form the extracted solution. From the table 4, it is shown that 3 principal components explain nearly $70 \%$ of the variability in the original 11 variables. In view of this, we can considerably reduce the complexity of the data set by using these 3 components, with only $11 \%$ loss of information.

\section{Scree Plot}

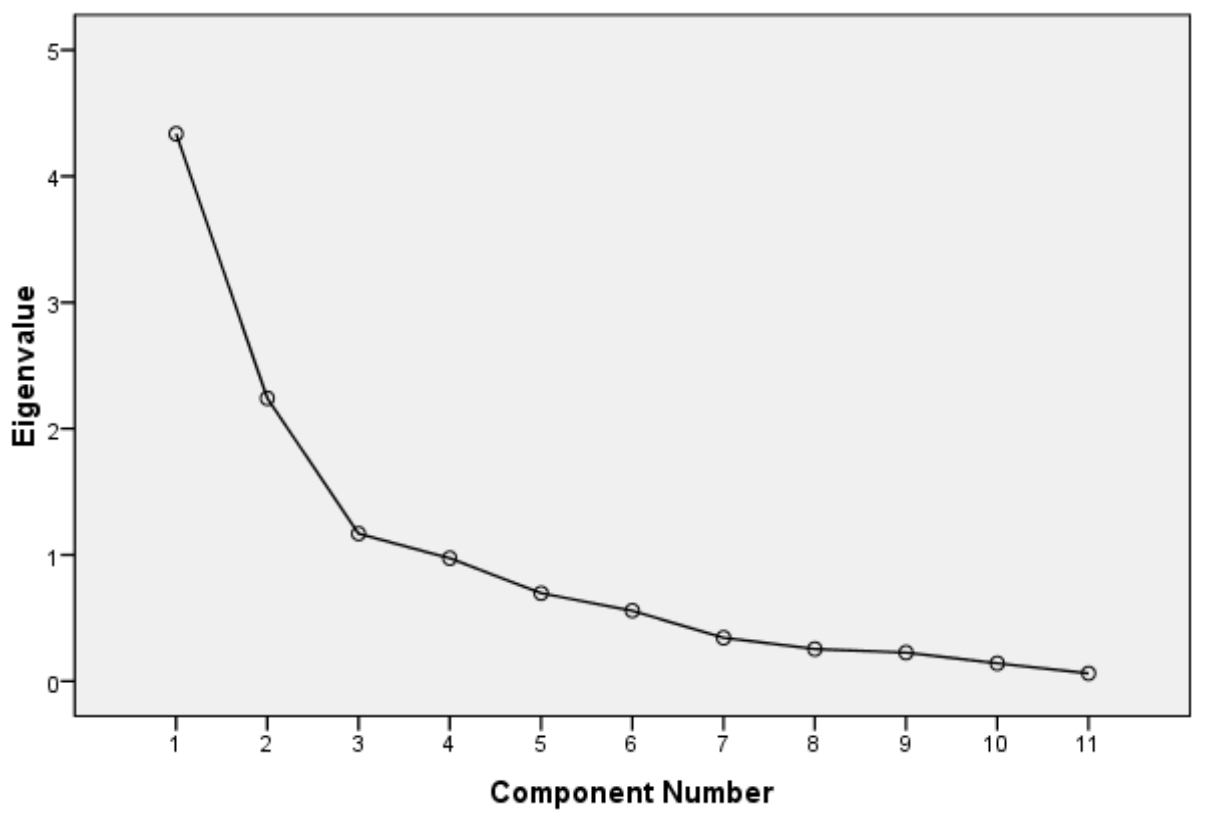

Figure 2 .

Source: Authors Field Survey.

The eigenvalue of each component in the initial solution is plotted on the scree plot, and it is indicated from the above figure that, 3 components are the optimal number of components on the steep slope. The components on the shallow slope contribute little to the solution. The last big drop occurs between the third and fourth components, so using the first 3 components is an easy choice.

Table 4(ii). Principal Component Factors (Generic) Influencing violent Behaviour Among Teenagers From Teachers' 
perception

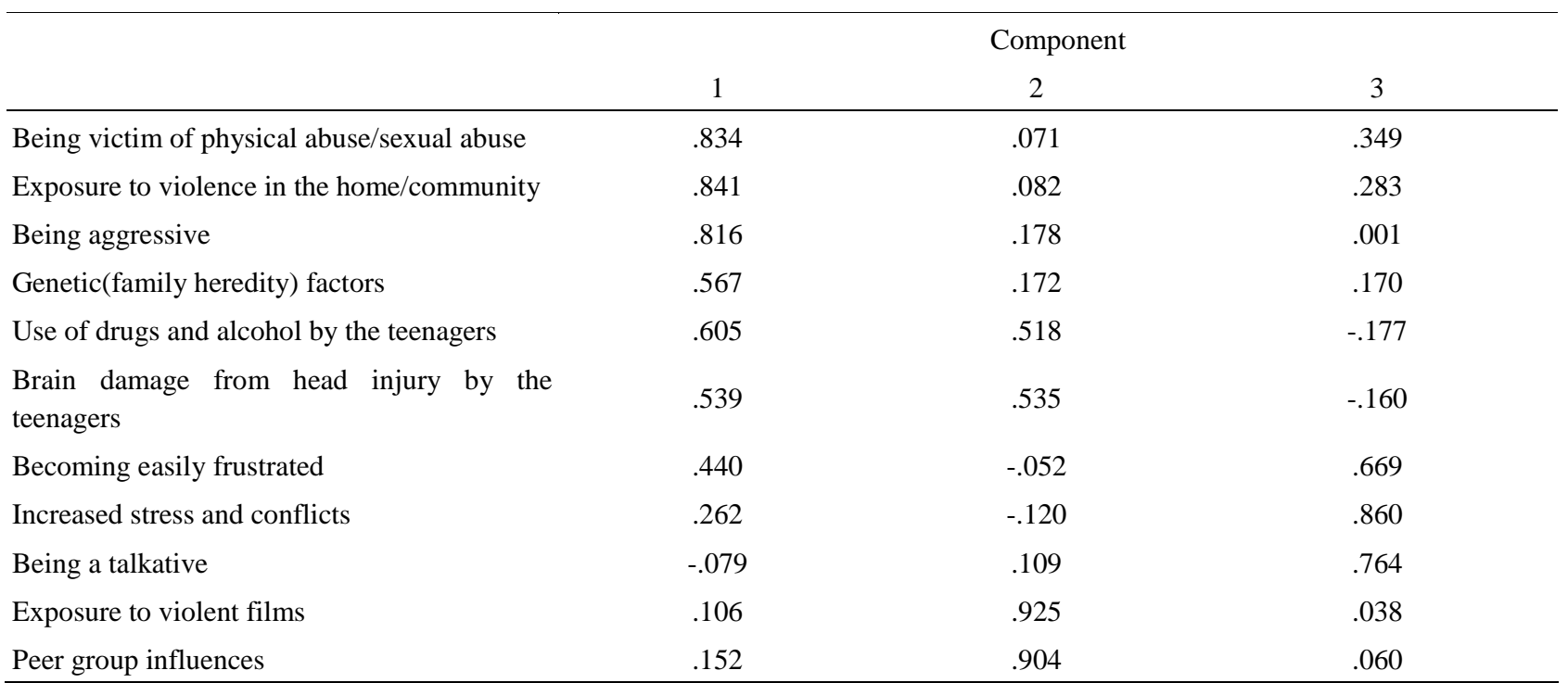

Source: Authors Field Survey.

It is indicated in Table 4(ii) that, there were three generic causes of violent behaviour among teenagers. The first component was highly correlated with being victim of physical abuse/sexual abuse and it has 0.834 component value. The second component was highly correlated with exposure to violent films and it has 0.925 component value. The third component was highly correlated with increased stress and conflicts and it has 0.860 component value.

So, it can be empirically deduced from the principal component analysis that, being victim of physical abuse/sexual abuse, exposure to violent films and increased stress and conflicts, form the generic perception of the teachers covered in the survey.

RESEARCH QUESTION 3: What are the methods of resolving violent behaviour among teenagers?

Table 5a. Methods of resolving Violent Behaviour among Teenagers.

\begin{tabular}{|c|c|c|c|c|c|c|}
\hline \multirow[b]{2}{*}{ Component } & \multicolumn{3}{|c|}{ Initial Eigenvalues } & \multicolumn{3}{|c|}{ Extraction Sums of Squared Loadings } \\
\hline & Total & $\%$ of Variance & Cumulative $\%$ & Total & $\%$ of Variance & Cumulative $\%$ \\
\hline 1 & 7.018 & 77.973 & 77.973 & 7.018 & 77.973 & 77.973 \\
\hline 2 & 6.933 & 10.365 & 88.338 & & & \\
\hline 3 & 5.618 & 6.867 & 95.204 & & & \\
\hline 4 & 4.165 & 1.832 & 97.037 & & & \\
\hline 5 & 3.112 & 1.249 & 98.285 & & & \\
\hline 6 & 2.080 & .893 & 99.178 & & & \\
\hline 7 & 1.046 & .515 & 99.694 & & & \\
\hline 8 & .028 & .306 & 100.000 & & & \\
\hline 9 & $1.166 \mathrm{E}-16$ & $1.296 \mathrm{E}-15$ & 100.000 & & & \\
\hline
\end{tabular}

Extraction Method: Principal Component Analysis.

Source: Authors Field Survey.

With the use of factor analysis, it is statistically required that eigenvalue greater than one (1) under total column is always extracted as the solution of the factor analysis. So, the first eigenvalue that is greater than one (1) under total column is the principal component that forms the extracted solution. From the table 5a, it is shown that 7 principal component explains nearly $78 \%$ of the variability in the original 9 variables. In view of this, we can considerably reduce the complexity of the data set by using these 7 components, with $78 \%$ loss of information. 
Table 5. Methods of resolving violent behaviour among teenagers

\begin{tabular}{|c|c|}
\hline & $\begin{array}{l}\text { Component } \\
1\end{array}$ \\
\hline $\begin{array}{l}\text { Disseminating information which condemns home violence by the } \\
\text { teachers }\end{array}$ & .910 \\
\hline $\begin{array}{l}\text { Schools arranging counseling professionals to educate teenagers on } \\
\text { violent behavior }\end{array}$ & .910 \\
\hline $\begin{array}{l}\text { Seminars and workshop should be encourage on violent behaviour in } \\
\text { schools }\end{array}$ & .909 \\
\hline Provision of violent free environment for teenagers by the school & .903 \\
\hline $\begin{array}{l}\text { Monitoring child's viewing of violence on TV/video movies by the } \\
\text { parents }\end{array}$ & .946 \\
\hline $\begin{array}{l}\text { Being a role model and working together to end violence in the } \\
\text { home }\end{array}$ & .945 \\
\hline Sex education and parenting programmes for teenagers & 0358. \\
\hline Prevention of child abuse by the government & 0.233 \\
\hline $\begin{array}{l}\text { Early interventions programmes for violent youngsters by the } \\
\text { government }\end{array}$ & .933 \\
\hline
\end{tabular}

\section{Source: Authors Field Survey}

It is shown from Table $5 \mathrm{~b}$ that, 7 variables have very high values that are very close to 1 . The implication of this is that, all these variables are good methods of resolving violent behaviour among teenagers. It is indicated in Table $5 \mathrm{~b}$ that, there were 7 good methods of resolving violent behaviour among teenagers. The first component highly correlated with disseminating information which condemns home violence by the teachers and it has .910 component value. The second component highly correlated with early interventions programmes for violent youngsters by the government and it has .933 component value. The third component highly correlated with being a role model and working together to end violence in the home and it has .945 component value. The fourth component highly correlated with monitoring child's viewing of violence on TV/video movies by the parents and it has .946 component value. The fifth component highly correlated with schools arranging counselling professionals to educate teenagers on violent behaviour and it has .910 component value. The sixth component highly correlated with seminars and workshop should be encouraged on violent behaviour in schools and it has .909 component value. The seventh component highly correlated with provision of violent free environment for teenagers by the school and it has .903 component value.

So, it can be empirically deduced from the principal component analysis that: disseminating information which condemns home violence by the teachers, early interventions programmes for violent youngsters by the government; being a role model and working together to end violence in the home; monitoring child's viewing of violence on $\mathrm{TV} / \mathrm{video}$ movies by the parents; schools arranging counseling professionals to educate teenagers on violent behavior; seminars and workshop should be encouraged on violent behaviour in schools, Provision of violent free environment for teenagers by the school were good methods of resolving violent behaviour among teenagers, from the teachers' perception covered in the survey.

\section{Discussion}

The study assessed the perception of teachers' on home factors contributing to violent behaviour among the teenagers. It specifically assessed the perception of teachers on how home factors contribute to violent behaviour among teenagers, identified the socio-generic causes of violent behaviour among teenagers and highlighted some of the methods of resolving violent behaviour among them.

Generally, the socio-demographic characteristics of the respondents showed that about $65 \%$ of the respondents were in their prime age. The gender distribution of the respondents indicated that we had more females (55.7 percent) than males (44.3 percent). The educational qualification of respondents revealed that 63.5 percent had National Certificate of Education, 26.1 percent had B.Sc./B.Ed and 10.4 percent had post graduate qualification. Based on the religion, understandably majority (798.3 percent) were Christians while 20 percent were Muslims while the remaining 2 respondents were traditionalists. In the same vein, the marital status of the respondents showed that 72.2 percent were married while 25.2 percent were single. It is shown from the analysis that 82.6 percent of the respondents were Yorubas, 
16.5 percent were Igbos while only one Hausa man was covered by the survey. The teaching experience of the teachers covered by the survey showed that $113(98.3 \%)$ of them had more than 5 years teaching experience. This tallied with the findings of Loper, Huffschmidst \& Ash (2001); Kaiser, \& Rasminsk (2003); Egbochukwu (2007); Wubs, Leif, Alan, Sheri, Hans, Sylvia \& Catherine (2009) and Briere, Simonsen, Sugai \& Myers (2015) who equally identified personality features, socio-demographic variations of their different regions.

Besides, it is shown from the factor analysis that, 6 home factors are the major factors contributing greatly to violent behaviour among teenagers. Those home factors according to the rotated component matrix are; having single parent, being over confidence, coming from poor home, over protection and dependency on the family, poor relationship between parents and children coming from wealthy home. These 6 home factors constitute about $95 \%$ of all the home factors contributing to teenage violence. These findings supported the views of Munn, Johnstone, Sharp \& Brown (2007); Poipoi, Agak, Kabuka (2010); Poipoi, Agak, Kabuka (2011); and Barbour (2015) who equally identified psychological and perceived home factors contributing to violence behaviour among public secondary schools in their different regions.

From the socio-generic factors angle, it was statistically captured that 3 out of the 11 factors contributed immensely to the causes of violent behaviour among teenagers in our society. Based on the principal component analysis conducted it was discovered that, being victim of physical abuse/sexual abuse, exposure to violent films and increased stress and conflicts were the major socio-generic factors contributing to teenage violence. These 3 socio-generic factors constituted about $90 \%$ of all the socio-generic factors contributing to teenage violence. The study equally tallied with the findings of Bonem, Stanley-Kime \& Corbin (2008); and Ndibalema (2013).

Lastly, 7 methods are the major factors of solving violence behaviour among teenagers, which were captured in the survey, and were considered appropriate by the teachers that the survey covered. This is in support of the view of Feuerborn, Trye \& King (2015) who provided a tool to achieve a systemic change through school wide positive behaviour intervention in solving violence behaviour among teenagers.

\section{Conclusion}

This study concluded that there are several home and generic factors contributing to violent behaviour among teenagers in our society. However, organizing sex education and parenting programmes by the school couple with monitoring the type of films the children watch by parents can go a long way in suppressing violent tendency among the teenagers. Government can also provide counseling professional in schools to sensitize teenagers on the inimical effect of violent behavior.

\section{Recommendations}

In view of the major findings derived, the following recommendations are made;

a. For credibility, acceptability and sustainability of the methods of curbing violent behaviour among teenagers, parents should be sensitized of their major roles as the first contact of the children and character builders of their wards.

b. The state ministry of education should deploy at least two school counselors to every school in the state. A feedback approach should also be put in place to know the progress made and other areas to improve on, regarding violent behaviour among teenagers.

c. Public enlightenment on the inimical impact of violent behaviour among the teenagers should be embarked on by the Non-Governmental Organizations and government agencies.

d. Organizing symposiums and seminars for the youths on the adverse effect of violent behaviour by renowned personalities (like Footballers, Book writers, Business men and women, Professors, Musicians, e.t.c.), where they will speak directly to the teenagers.

e. Every school and home should place high value on religion, so that children know that no religions support violent behaviour

\section{References}

Barbour, S. (2015). What are the causes of violent behaviour in children? Available online at livestrong.com>parent>children>kid behavior London online University of Reohampton

Bonem, M., Stanley-Kime, K. L., \& Corbin, M. (2008). "A Behavioural Approach to domestic violence". Journal of Behaviour Analysis of Offender and Victim: Treatment and Prevention, 1(4), 210-213.

Briere, D. E., Simonsen, B., Sugai, G., \& Myers, D. (2015). Increasing New teachers' specific praise using a within school consultation Intervention. Journal of Positive Behaviour Interventions, 17, 50-60.

Dahlberg, L. L., \& Krug, E. G. (2002). Violence - a global public health problem. In King E, Dahlbergl, Meray J. A., \& 
Zwi. A. B.

Dodd, L. W. (2009). "Therapeutic groupwork with young children and mothers who have experienced domestic abuse". Educational Psychology in Practice, 25, 21-36.

Egbochukwu, E. O. (2007). Bullying in Nigerian schools: Prevalence study and implications for counseling. Journal of Social Science, 14(1), 65-71.

Feuerborn, L. L., Tyre, A. D., \& King, J. P. (2015). The staff perceptions of Behavior and Discipline survey: A tool to help achieve systemic change through school wide Positive Behaviour support. Journal of positive Behaviour International, 17, 116-126.

Kaiser, B., \& Rasmink, J. S. (2003). Challenging baehaviour in young children: Understanding, preventing and responding effectively. Boston: Pearson.

Kangare, W. (2008). Sexual violence in Kenya. Nairobi: Nairobi publishers [http://www.planetwire.org/fi les.fcgi/6283_ SexualViolenceKenya.doc] (10 October 2008).

Kitzmann, K. M., Gaylord, N. K., Holt, A. R., \& Kenny, E. D. (2003). Child witnesses to domestic violence: A meta-analytic review. Journal of Consulting and Clinical Psychology, 71, 339-352.

Lazenbatt, A., Thompso-Cree, M. E. (2009). "Recognizing the co-occurrence of domestic and child abuse: A comparison of community-and hospital-based midwives". Health \& Social Care in the Community, 17(4), 358. http://dx.doi.org/10.1111/j.1365-2524.2009.00833.x

Leach, F. (2003). Learning to be violent: the role of the school in developing adolescent gendered behaviour. Compare, $33,385-400$.

Lehmann, P. J. (1995). Children who witness mother-assault: An expander posttraumatic stress disorder conceptualization (M.A. Thesis) Wilfrid Laurier University.

Loper, A. B., Huffschmidst, S. F., \& Ash, E. (2003). Personality features and characteristics of violent events committed by violence Offenders Behaviour. Science law, 19, 81-96.

Miller, D. (2010): Children's Exposure to Violence - Community Violence, Domestic Violence - General Effects.

Munn, P., Johnstone, M., Sharp, S., \& Brown, J. (2007). Violence in schools: Perceptions of secondary teachers and head teachers over time. International Journal on violence and schools, 3, 51-81.

Mutsotso, S. N. (2004). The role of social education and ethics in the management of student violence in secondary schools in Vihiga District Kenya. Unpublished Doctor of Philosophy Thesis, Moi University Library. Eldoret.

Ndibalema, P. (2013). Perception about bullying behaviour in secondary school in Tanzania. The case of Dodoma municipality. International journal of Education and Research, 195, 1-16.

Obi, S. N., \& Ozumba, B. C. (2007) Factors associated with domestic violence in South-East Nigeria. Journal of Obstetrics and Gynaecology, 27(1), 75-78.

Ohsako, T. (2007): Studies in comparative Education. Violence at school: Global issues and Interventions. UNESCO. International Bureau of Education. Lausanne: Switzerland by Presses Centrales.

Poipoi, M. W., Agak, J. O., \& Kabuka, E. K (2010). Teachers and students' pereption of psycho-physiological factors contributing to violent behaviour among public secondary school students in Western Province. Kenya International Research journal, 1(10), 463-476.

Poipoi, M. W., Agak, J. O., \& Kabuka, E. K (2011). Perceived Home factors contributing to violent behaviour among public secondary school students in Western province, Kenya. Journal of Emerging Trends in Educational Research and Policy studies, 2(1), 30-40.

Rukundo, B.M. (2009) Relationship between management and strikes in the secondary schools of Uganda: a case study of Ntungamo District. Unpublished master's degree. Makerere University. Kampala.

Ruto .J. S (2009). Sexual Abuse of School Age Children: Evidence from Kenya. CICE Hiroshima University. Journal of International Corporation Education, 12(1), 177-192.

Simatwa, W. M. E. (2007). Management of school discipline in secondary schools in Bungoma District, Kenya. Unpublished Doctor of philosophy dissertation Maseno University Maseno.

UNICEF (2001). Children and Women's rights in Nigeria: A wake up call situation assessment and analysis. Edited by Hodge. Abuja:

UNICEF (2005). Violence at home (archive) Voices of Youth Forum. Retrieved Oct. 2008 from 
http://www.unicef.org/roy/ discussions/archieve/index.

Volpe, J. (1996). Effects of Domestic Violence on Children and Adolescents: An Overview. American Academy of Experts in Trauma Stress, Inc.

Wubs, G. A., Leif, E. A., Alans, J. P., Sheri, B., Hans, E.O., Sylvia, K., \& Catherine, M. (2009), Dating Violence amog school students in Tanzania and South Africa: Prevalence and Socio-demographic variations. Scandinavian Journal of Public Health, 37(2), 75-86.

\section{(cc) $\mathrm{BY}$}

This work is licensed under a Creative Commons Attribution 3.0 License. 